\title{
Občestvo kljub različnosti. Pavlovo razumevanje koinonie v Pismu Galačanom (Gal 2,9)
}

\author{
Communion in spite of Diversity. \\ Paul's Understanding of Koinonia in the \\ Letter to Galatians (Gal 2,9)
}

Povzetek: Članek obravnava biblični model reševanja konfliktov in iskanja edinosti ob sreče-

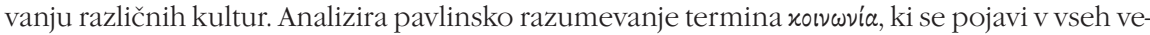
likih Pavlovih pismih, v Pismu Galačanom pa ima ključno vlogo pri razumevanju sporazuma, ki je bil sklenjen na zboru apostolov v Jeruzalemu med Pavlom in Barnabom ter vodilnimi

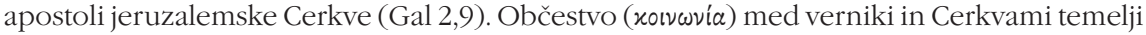
v vzajemnem priznanju "resnice evangelija«, ki vsem odpira pristop v občestvo Božjega ljudstva po veri v Jezusa Kristusa. Termin xoเvwvía dobi tako v Pismu Galačanom poleg kristološke in ekleziološke tudi ekumensko in etično konotacijo ter predstavi model dinamične občestvene Cerkve, ki kljub različnim kulturam in pristopom ohranja edinost ter pričuje za novo življenje v Kristusu, ki se zaveda svojega misijonskega in ekumenskega poslanstva. ${ }^{1}$

Ključne besede: Pismo Galačanom, Pavlov evangelij, jeruzalemski zbor, evangelizacija, dialog, edinost, občestvo, deležnost, koinonia, ekumenizem, Cerkev

Abstract: The article discusses the biblical model of conflict resolution and the search for unity
when encountering different cultures. It analyzes the Pauline understanding of the term
xolv wrí, which appears in all great Paul's letters and plays a key role in Letter to Galatians
in understanding the agreement that was made at the choir of the apostles in Jerusalem
between Paul and Barnabas and the leading apostles of the Jerusalem Church (Gal 2,9).
The Communion (xolvwi'a) between believers and the Churches is based on the mutual
recognition of the "truth of the Gospel", which opens the way to all the people to join the
communion of the people of God through faith in Jesus Christ. Beside the christological and
ecclesiological connotation the term xolvwria in the Letter to Galatians also gets ecumenical
and ethical connotation and presents the model of the dynamic communion of the Church,

1 Prispevek je nastal kot rezultat dejavnosti raziskovalnega programa P6-0262 Judovsko-krščanski viri in razsežnosti pravičnosti, ki ga je sofinancirala Javna agencija za raziskovalno dejavnost Republike Slovenije iz državnega proračuna. 
which, despite different cultures and approaches, preserves unity and testifies to a new life in Christ conscious of its missionary and ecumenical mission.

Key words: Letter to Galatians, Paul's Gospel, Jerusalem assembly, evangelism, dialogue, unity, communion, share, koinonia, ecumenism, church

\section{Uvod}

Naloga teologije je omogočati človeku razmislek o temeljnih razsežnostih njegovega izvora, življenja in prihodnosti ter mu s tem pomagati ustvarjati odnose za čim bolj celostno življenje. Še posebej v času velikih sprememb, pretresov in iskanj, ki smo jim tudi danes priča tako v družbi kot v Cerkvi, mora teologija prispevati svoj delež k reševanju konfliktov in iskanju edinosti. Leta 2016 je mešana luteransko-rimskokatoliška komisija za edinost pripravila dokument z naslovom Od konflikta do skupnosti. V njem ugotavlja, da bi morali kristjani »vedno izhajati iz perspektive edinosti, in ne iz perspektive ločitve, da bi krepili to, kar imajo skupnega, tudi če je veliko lažje videti in doživljati razlike« (Od konflikta do skupnosti 2016, 239). To je bila tudi perspektiva prve Cerkve, ki se je pri prenosu Kristusovega evangelija v svet morala že na začetku spopasti z dvema resnima izzivoma: na eni strani z močno judovsko tradicijo, iz katere je $v$ resnici rastla, a je obstajala toliko večja nevarnost, da ob njej spregleda in zanemari svojo novo identiteto, ki ji jo daje evangelij, ter se razdeli glede na etnične ali idejne delitve, na drugi strani pa z bogato grško-rimsko kulturo, v katero je vstopala in katere jezik in način življenja je začela spontano uporabljati. (Matjaž 2012, 568-571)

Glede prizadevanja za edinost in graditev trdnega občestva, ki vzdrži tudi naporne procese prečiščevanja in osvobajanja, zasluži posebno pozornost Pavlovo Pismo Galačanom. V njem smo priča napetostim med Pavlovim oznanilom evangelija, ki je postavljen na izključni Kristusovi odrešenjski daritvi, ter jeruzalemsko Cerkvijo, ki je prepričana, da bi morali kristjani še vedno upoštevati določene predpise judovske Postave. V razpravi bomo predstavili Pavlova prizadevanja, da prepriča o »resnici evangelija« $(2,5)$, ki ga je prejel po razodetju in ki je edini temelj novega življenja. Osrednja pozornost bo veljala Pavlovemu drugemu obisku v Jeruzalemu, kjer je prišlo do sklenitve občestva med njim in Barnabom ter vodilnimi apostoli

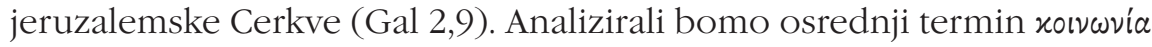


(občestvo, skupnost, vzajemnost, deležnost) v njegovem ožjem in širšem kontekstu Pisma Galačanom, da bi pridobili širši pogled na Pavlovo razumevanje Cerkve kot občestva.

\section{Evangelij posinovljenja - temelj edinosti}

V Pismu Galačanom se apostol Pavel pokaže kot zelo odločen in kritičen voditelj skupnosti, ki ni pripravljen sklepati nobenih kompromisov, da bi si pridobil naklonjenost ljudi $(1,10)$ ali da bi se izognil preganjanju $(5,11$; 6,12). Že v uvodni vrstici poudari, da je svoje apostolstvo sprejel po Jezusu Kristusu od Boga Očeta in ni izbran "ne od ljudi ne po človeku« (1,1: oủx

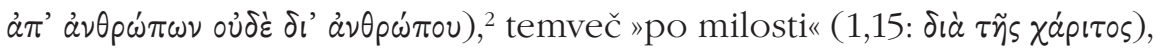
da ni drugorazredni apostol in da je torej njegovo učenje verodostojno. Pisma ne začenja z običajno pohvalo in zahvalo naslovljencem, temveč s kritičnim čudenjem nad njihovim hitrim odvračanjem od Kristusa in njegovega evangelija ter iskanjem nekega »drugega evangelija» (1,6-7). Tudi v zaključku se Pavel odpove obliki običajnega pozdrava ter namesto tega še enkrat opozori pred vsiljivimi novimi oznanjevalci, ki jih silijo v obrezo (6,12-14). Nad temi, ki oznanjajo neki drug evangelij, kakor ga oznanja on, in pravi Kristusov evangelij obračajo na glavo $(1,7 \mathrm{~b})$, izreče v uvodu kar dvakrat grozeč izrek »naj bo izobčen« (å่ $\alpha^{\prime} \theta \varepsilon \mu \alpha$ है $\left.\sigma \tau \omega\right)(1,8.9)$.

Kdo so Pavlovi nasprotniki, ki so se pojavili v galaških skupnostih in proti katerim je apostol tako odločno nastopil? Večina razlagalcev je prepričana, da gre za judovsko-krščanske misijonarje, ki so bili povezani z bolj tradicionalnimi krogi okrog Jakoba in jeruzalemske Cerkve in ki se niso mogli sprijazniti s Pavlovo relativizacijo pomena postave. (Lührmann 1978, 104-108; Mußner 1981, 25) 3 Ti posamezni oznanjevalci so v galaških skupnostih

2 Antitetični stil, s katerim se apostol predstavi takoj na začetku in naveže na formulo poklica preroka (Am 7,14), je značilen za argumentacijski postopek v celem pismu (Betz 1979, 38; Pitta 2009, 65).

3 Drugače meni Söding (1991, 315-316), ki je prepričan, da gre za helenistične judeo-kristjane, ki se spogledujejo z nominalizmom in sinkretizmom. Pavel jim namreč očita, da se želijo vrniti k bogovom, »ki to po naravi niso«, $\mathrm{k}$ »bednim prvinam«, ter »obhajati dneve, mesece, letne čase in leta« (4,3.8-10). Ti očitno ne zagovarjajo obreze $(5,11 ; 6,15)$. Gotovo so bili med Pavlovimi nasprotniki tudi samooklicani branilci »resnice«, ki sta jih motila Pavlova svoboda in njegov uspeh. Pregled različnih hipotez predstavi Howard (1979, 1-19). 
očitno hitro pridobili velik vpliv, ${ }^{4}$ tako da je veliko teh, ki so na začetku Pavlu popolnoma zaupali (4,13-15; 5,7), začelo dvomiti, ali je on res pravi apostol in ali jim je oznanil celotni evangelij $(1,6-8)$. Pavel nastopi odločno, ker je prepričan, da ne gre samo za vprašanje obreze in judovskih običajev, ampak za centralno teološko vprašanje o temeljni»resnici evangelija « $(2,5 \mathrm{~b}$ :

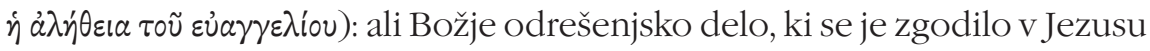
Kristusu in so ga verniki sprejeli v krstu, ko so »oblekli Kristusa« (3,26-27), zadostuje za sklenitev zaveze $z$ Bogom, po kateri verniki stopajo v občestvo Božjega ljudstva Abrahamovih sinov $(3,7)$, ali pa bo ta zaveza v resnici

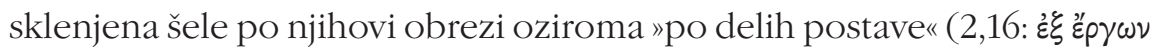
vópov). Galačane želi na različne načine prepričati o prvem - o odrešenjski moči edinega Kristusovega evangelija, ki jim ga je oznanil (2,16-21). Najprej tako pričuje o svoji izkušnji doživetja Kristusa, ki je bilo končno milostno delo Boga, ki mu je do tedaj služil v judovstvu s »strastno vnemo za očetna izročila« $(1,14)$. Ta milost zdaj deluje tako v njem kot v drugih apostolih (2,7-8). Želi jih prepričati o razodetju, ki ga je prejel, da lahko vsi po veri

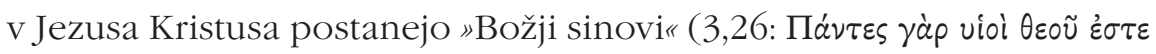

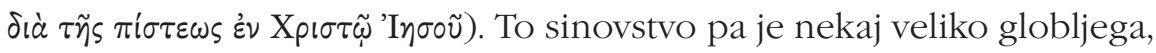
kot so razlike med Judi in Grki, med sužnji in svobodnimi, med moškimi

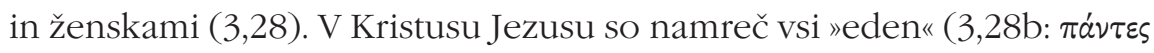

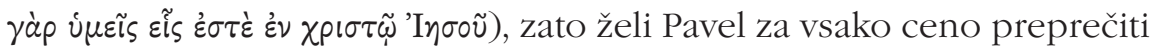
razdor med obrezanimi in neobrezanimi verniki ter doseči edinost vseh

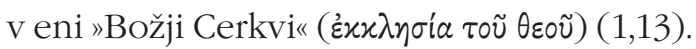

Pismo je prav zaradi osrednjega ekleziološko-kerigmatičnega namena premišljeno retorično sestavljeno. ${ }^{5} \mathrm{~V}$ duhu klasične retorične argumentacije ${ }^{6}$

4 Nanos $(2002,193)$ uporablja za te ljudi, ki po njegovem mnenju niso bili organizirani v neko enotno skupino, nevtralen izraz influencers, kar bi lahko prevedli z vplivniki. Tudi Pitta (2009, 52-56) meni, da gre za ljudi različnih ozadij, ki niso nujno Pavlovi nasprotniki, ampak bolj »agitatorji« različnih prepričanj, ki so čutili potrebo, da morajo Pavlovemu učenju še kaj dodati.

$5 \mathrm{~V}$ pismu se prepletajo različni kerigmatični in retorični elementi, zato si raziskovalci niso edini, kako opredeliti pismo glede na vrsto retorike, ki jo Pavel uporablja. Aktualen pregled raziskav navaja Pitta (2017, 156-162). Najodmevnejšo tovrstno analizo je v sodobnem času opravil Betz (1979, 14-23), ki je obliko pisma opredelil kot apologetično ali sodno retoriko z epistolarnimi elementi in predlagal naslednjo osnovno stukturo: epistolarni uvod (1,1-5), exordium (1,6-11), narratio $(1,12-2,14)$, propositio (2,15-21), probatio $(3,1-4,31)$, exhortatio $(5,1-6,10)$ in conclusio $(6,11-18)$. Kasneje sta stopila bolj v ospredje deliberativni vidik retorike in Pavlov namen, da prepriča Galačane, naj se odpovejo obrezi (Gal 5-6) (Smit 1989, 1-25). Pavel je gotovo združil več različnih retoričnih oblik in jim dal svojstveni pečat (Hansen 1989, 54-71). Tako vsebino kot tudi obliko pisma pa so bistveno zaznamovale okoliščine njegovega nastanka. 
uporablja Pavel na začetku pisma predvsem avtobiografske in ekleziološke elemente, v drugem delu pa izstopa biblična argumentacija, še posebej uporaba midrašev (3,6-14; 4,21-31), ${ }^{7}$ kjer želi predvsem dokazati vključenost vseh, ki so sprejeli evangelij, v Abrahamovo zavezo in hkrati njihovo svobodo od judovske postave.

\section{Srečanje s Cerkvijo v Jeruzalemu}

Pavel se z namenom, da bi prepričal Galačane o resničnosti »svojega« evangelija o Jezusu Kristusu, sklicuje na svoje obiske Jeruzalema in srečanje z vodilnimi apostoli tamkajšnje Cerkve, ki jim je predstavil svojo misijonsko dejavnost. Prvič je obiskal Jeruzalem okrog tri leta po dogodku pred Damaskom $(1,18)$, ko se je spoznal s Kefom, tam ostal 15 dni in se na kratko srečal tudi z Jakobom, Gospodovim bratom (v. 19). Iz opisa se dovolj jasno vidi, da Pavel ne želi dajati vtisa, da bi bil njegov evangelij odvisen od Petrove kerigme ali od jeruzalemske tradicije; njegov evangelij ni sad »mesa in krvi«(1,16: бapxi xai ail $а \tau \iota)$, ampak Božjega razodetja. Bog sam mu je razodel svojega Sina "z namenom, da bi oznanjal njegov evan-

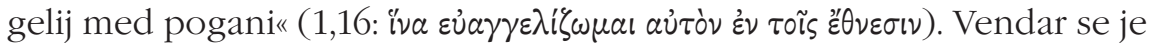
Pavel očitno zavedal, da bo obisk pri apostolih v Jeruzalemu zelo pomemben za njegovo nadaljnje misijonsko delovanje, zato izpostavi srečanje s Kefom. Opis razkriva, da ga ni »obiskal« na isti način kot Jakoba, ki ga

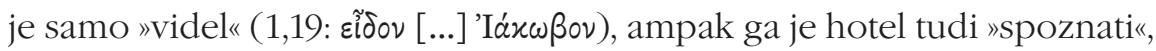
se z njim posvetovati, kar lahko sklepamo iz uporabe neobičajnega gla-

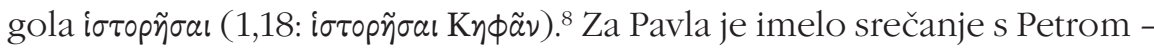
Kefom tako vsebinski kot ekleziološki pomen, saj ga ima za prvo pričo Kristusovega evangelija. ${ }^{9}$ Prav on tudi največkrat od vseh piscev Nove

7 Pregled razprav o Pavlovi uporabi Stare zaveze, še posebej o njegovi biblični argumentaciji v Gal, opišejo Hansen (1989, 12-30), Pitta (2008, 136-160) in Stanley (1998, 700-730).

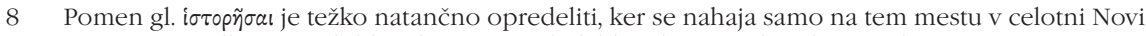
zavezi. Na podlagi izvenbibličnih primerov bi lahko gl. prevajali tudi v smislu spoznavanja, posvetovanja, raziskovanja, poglabljanja. (Matera 1992, 66; Mußner 1981, 94; Pitta 2009, 101-103) Slednji navaja grške vire in sodobne avtorje.

9 Večina vzhodnih kodeksov (P46, P51, S*, A, B) vsebuje tukaj semitsko poimenovanje Knфãv, nekateri zahodni kodeksi pa uporabljajo grško ime Пદ́tpov (S² D, F, G, Syr) (Betz 1979, 76; Schwarz 1992). 


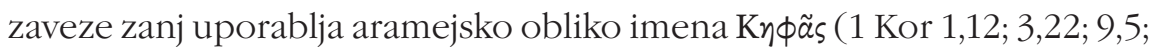
15,$5 ;$ Gal 1,18; 2,9.11.14). ${ }^{10}$

Obisk Jeruzalema, o katerem poroča v 2,1-10, je bil torej »naslednji«

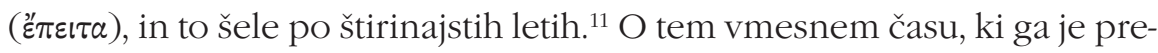
živel na področjih Sirije in Kilikije, piše Pavel zelo na kratko v 1,21-24. Iz Lukovega opisa v Apd 9,26-30 lahko sklepamo, da so mu v Judeji in v Jeruzalemu stregli po življenju in je moral od tam zbežati. Vsekakor pa je v tem času tudi že oznanjal evangelij, čeprav očitno bolj na skrivaj. Sam piše, da je bil »Cerkvam po Judeji, ki so v Kristusu« $(1,22)$, nepoznan, le sli-

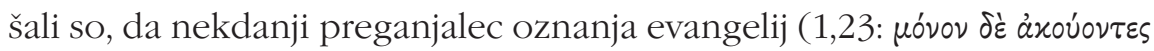

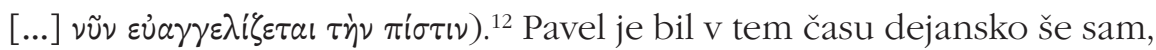
brez skupnosti in brez sodelavcev ter tako tudi brez Cerkve, v imenu katere bi lahko »uradno« oznanjal evangelij. Barnaba ga šele precej kasneje pride iskat v Tarz, da bi ga pridobil za svojega sodelavca v Antiohiji (Apd 11,25-26). Tako so verniki v Jeruzalemu lahko o njem slišali samo kot o spreobrnjenem preganjalcu, ki je nekoč skušal vero zatreti (1,23; 1,13; Apd

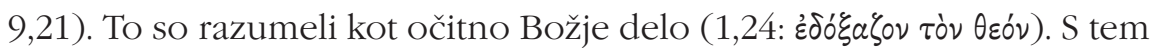
najzgodnejšim pričevanjem Cerkve v Judeji o Pavlu in o njegovem spreobrnjenju, ki je prispevalo k rasti vere tudi v jeruzalemski Cerkvi, se zaključi prvi del avtobiografske argumentacije o verodostojnosti Pavlovega evangelija. ${ }^{13}$

O svojem drugem obisku Jeruzalema poroča Pavel Galačanom še bolj podrobno (2,1-10), saj jih je hotel tako prepričati, da tudi vodilni v jeruzalemski Cerkvi soglašajo z njegovim evangelijem in z njegovim oznanjevanjem med pogani $(2,2)$. Najprej izpostavi, da se je za obisk Jeruzalema

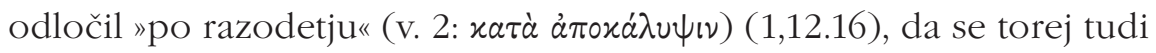

10 Izven pavlinskega korpusa srečamo ime Knфãs samo še v Jn 1,42.

11 Natančni kronološki podatki dajo dodatno težo pomembnosti tega obiska v Jeruzalemu. Obstajajo sicer določena neskladja med Pavlovo in Lukovo kronologijo v Apd, čemur pa je lahko vzrok tudi različna perspektiva poročanja (Das 2014, 31-43).

12 Gre za najstarejše novozavezno pričevanje o veri preganjane judovsko-krščanske skupnosti (Matera 1992, 68; Longennecker 1990, 41; Pitta 2009, 109).

13 Vanhoye $(2000,51)$ je prepričan, da lahko na podlagi tega pričevanja dejansko govorimo o Pavlovem spreobrnjenju, saj je srečanje s Kristusom radikalno spremenilo njegovo življenje, njegove usmeritve in vrednote, o čemer pričuje tudi sam v Flp 3,7-11. 
ta njegov korak ni zgodil po človeški pobudi in da v to ni bil kakorkoli prisiljen. ${ }^{14}$ Opis dogodka se po večini sklada z Lukovim v Apd 15,1-34, pomenljive pa so tudi razlike, ki kažejo, da zasleduje vsak svojo lastno narativno in teološko perspektivo. ${ }^{15}$ Luka poroča, da so se zbrali apostoli

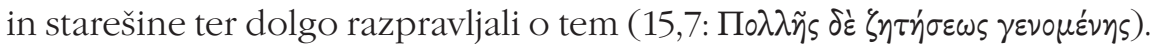
Barnaba in Pavel jim sicer nista predstavila same vsebine evangelija, temveč to, »kako velika znamenja in čudeže je Bog storil po njiju med pogani« (v. 12). To se na neki način ujema s Pavlovim zapisom, ki tudi ne omenja, da bi bil predmet razprave evangelij kot tak, kar je zanj razumljivo, saj ga je prejel "po razodetju« (Gal 1,12). Luka tudi obširno poroča o interventu, ki sta ga imela na zboru Peter in Jakob, ko sta na podlagi Svetega pisma utemeljevala, da je Pavlovo oznanjevanje evangelija poganom v skladu z Božjim načrtom (Apd 15,7-19). Jakob v sklepu predlaga sprejetje priporočil, naj se spreobrnjeni pogani vzdržijo dejanj, ki bi lahko prizadela judovske obredne predpise $(15,20.29)$, česar pa Pavel prav tako ne omenja.

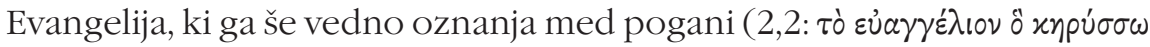

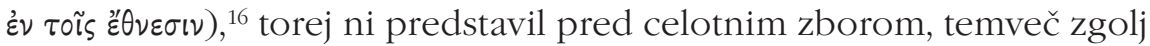

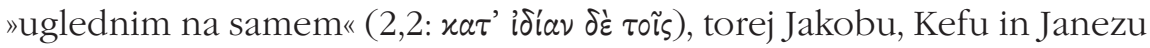
(v. 9). Med zbrane v zboru so se namreč »vrinili lažni bratje, da bi prežali

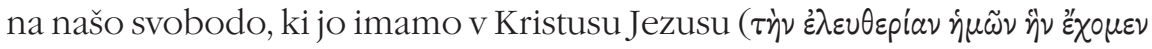

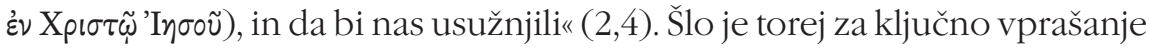
svobode - to je novega življenja, ki ga podarja Kristus. Zaveda se, da lahko o tem, kaj spada k temeljni resnici razodetega Kristusovega evangelija, presoja samo skupaj z apostoli, ki jih je izbral Gospod sam. Pomenljivo

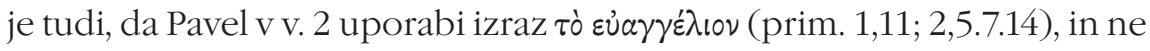

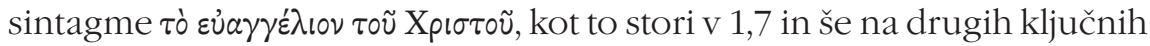
mestih. ${ }^{17}$ Med raziskovalci prevladuje prepričanje, da ne gre zgolj za sinonimne izraze, ki bi jih Pavel poljubno uporabljal, temveč želi z njimi

14 S sklicevanjem na razodetje Pavel nedvomno tudi ta dogodek razume kot sad navdiha Svetega Duha, ki gradi Božjo cerkev, in ne kot rezultat človeških motivacij (Betz 1979, 62; Das 2014, 120-122); drugače meni Matera $(1992,72)$.

15 Pregled podobnosti in razlik med Gal 2,1-10 in Apd 15,1-34 predstavi Mußner (1981, 128-132). Čeprav večina raziskovalcev soglaša, da se odlomka nanašata na isti dogodek, obstajajo v Pavlovem opisu določeni elementi, ki se bolj skladajo z dogodki v Apd 11,27-30 ali v Apd 18,22. Pregled različnih variant in raziskav opiše Pitta (2009, 126-128).

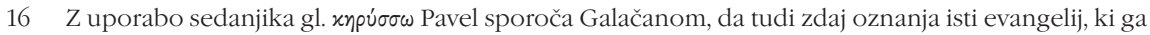
je predstavil vodilnim $v$ Jeruzalemu.

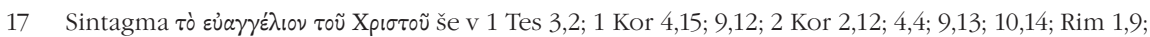

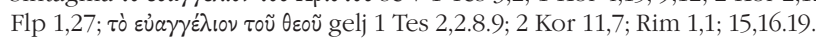




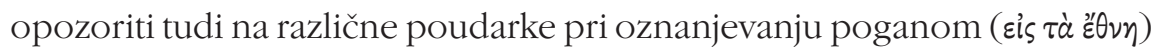

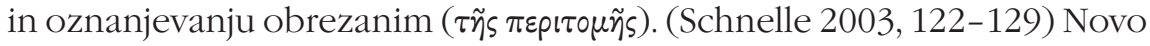
življenje, rojeno iz krsta in osvobojeno postave, spada gotovo k osnovnemu sadu Kristusovega evangelija. Vprašanje glede načinov, kako živeti in ostati v tem daru novega življenja, pa bi lahko kristjane iz judovstva in poganstva usodno razdvajalo, zato ga želi Pavel razrešiti v občestvu z najuglednejšimi člani jeruzalemske Cerkve. Sam je namreč že izkusil, da Bog kliče ljudi k veri v Kristusov evangelij na veliko načinov.

Resnost njegovega namena, da prepriča Galačane o verodostojnosti »njegovega« evangelija, je mogoče razbrati tudi iz značilne fraze $\mu \eta \dot{\eta} \pi \omega \varsigma$ (»da bi ne«), ki jo srečamo samo pri Pavlu in izraža neko realno nevarnost in strah,

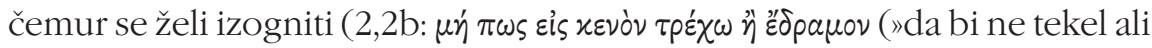
da nisem tekel zaman«) (prim. 4,11; 1 Tes 3,5; 1 Kor 8,9; 9,27; 2 Kor 2,7; 9,4; $11,3 ; 12,20)$. Ni razlogov, da bi njegov strah, ki ga izrazi s svojo priljubljeno športno metaforo, ${ }^{18}$ povezovali z dvomom glede same resnice evangelija, o kateri govori v 2,5.14. Boji se za svojo skupnost, da jim je zaman oznanjal evangelij in še vedno raje živijo pod jarmom Postave. Ta strah kasneje v pismu jasno izrazi: „Bojim se za vas, da sem se morda (фоßоũ $\mu a \imath$ ú $\mu \tilde{s}$ $\left.\mu \eta^{\prime} \pi \omega \varsigma\right)$ zaman trudil za vas.» $(4,11)$

Tudi dvakratna omemba Tita v odlomku $(2,1.3)$ pomembno razkrije okoliščine dogodka in Pavlovo strategijo. Tit je očitno smel biti s Pavlom (ó oìv $\left.\varepsilon \dot{\varepsilon} \mu{ }^{\prime}\right)$ na samem zboru kot enakopravni član delegacije, čeprav je bil neob-

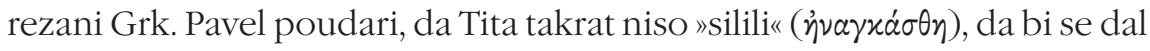
obrezati, in so s tem dejansko že potrdili, da obreza ni pogoj za pripadnost "Cerkvi, ki je v Kristusu« $(1,21)$. To lahko razumemo kot neko paradigmatično napoved polnega cerkvenega občestva tudi za vse ostale "grške« Oziroma poganske ali »etnokristjane« ${ }^{19}$ Morda ga je Pavel pripeljal s seboj prav $\mathrm{z}$ namenom, da izzove zbor $\mathrm{k}$ jasni odločitvi glede njegovega apostolata.

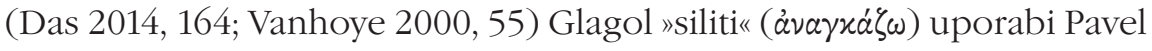
še dvakrat, ko v naslednjem odlomku poroča o sporu s Kefom v Antiohiji,

18 Gal 5,7; Rim 9,16; 1 Kor 9,24-27; Flp 2,16; 3,12-14. Raziskave o tej pavlinski športni metafori grškega izvora predstavi Pitta $(2009,114)$

19 Termin "E $\lambda \lambda \eta \nu$ (Helen, Grk) lahko tu razumemo kot sinonim za termin है $\theta$ vos pripadnik naroda, pogan ( $\operatorname{Rim} 1,16 ; 2,9.14 .20)$, iz katerega izpeljujemo tudi besedo »etnokristjan « kot oznako za kristjane iz poganstva. 


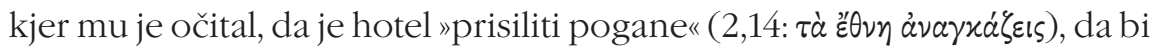

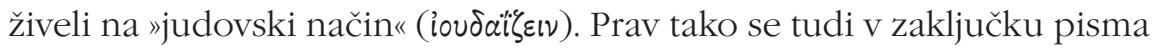

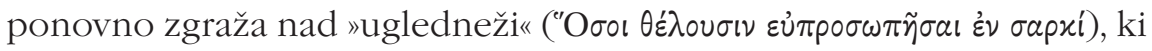
"silijo" Galačane, da bi se dali obrezati, in jim celo grozijo s preganjanjem $(6,12)$. S tem kontrastom med pozitivnim ravnanjem in naklonjenostjo jeruzalemskih starešin do njega samega in do njegovega oznanila ter zadrtostjo lažnih oznanjevalcev, ki so se pojavili med Galačani, želi še bolj spodbuditi svoje skupnosti, naj mu zaupajo in naj tudi sami uvidijo, kaj spada k resnici evangelija in kaj jih vodi v staro sužnost. Tudi trditev v v. 6,

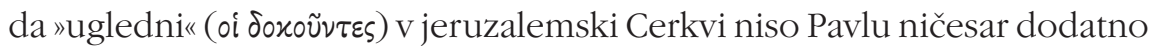
naložili, postavlja njegove nasprotnike na laž. ${ }^{20}$ Pomenilo je tudi poraz »lažnih bratov« v samem zboru (v. 4), ki so zahtevali obsodbo Pavlovega načina oznanjevanja. Pavel je s tem ne le dosegel glavni namen svojega obiska v Jeruzalemu, temveč je v soočenju različnih idej in praks izoblikoval neko

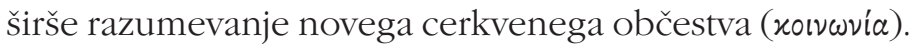

\section{Sadovi jeruzalemskega zbora in potrditev občestva}

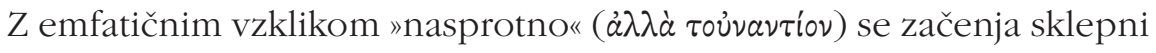
del odlomka (2,7-10), kjer Pavel predstavi sadove srečanja s Cerkvijo

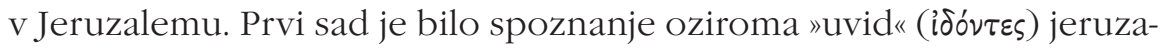
lemske Cerkve, da je bil Pavlu od Boga "zaupan (ö $\tau \iota \pi \varepsilon \pi i \sigma \tau \varepsilon u \mu a \iota)^{21}$ evangelij za neobrezane, kakor je bil Petru za obrezane«(v. 7). Rečemo lahko, da je prišlo do novega, celovitejšega pogleda na cerkveno občestvo ( ki se je oblikoval tako na podlagi Pavlove pripovedi o evangeliju, ki ga je prejel po razodetju Jezusa Kristusa (1,11sl.), kot na podlagi tega, kar so slišali o njegovi misijonarski aktivnosti (1,23-24), in tega, kar je o vsebini svojega oznanjevanja na samem zaupal uglednim $(2,2)$. Iz vsega tega je nastala neka nova, širša vizija misijonarskega poslanstva Kristusove Cerkve.

20 Ta izjava je problematična, če izhajamo iz predpostavke, da je bilo apostolsko pismo, kjer jeruzalemski voditelji navedejo določene predpise postave, ki naj se jih držijo tudi spreobrnjeni pogani in o katerem poroča Luka v Apd 15,22-29, sestavni del sporočila jeruzalemskega zbora. Pavel namreč teh določil v Gal ne omenja. Morda je šlo za dva ločena dogodka, lahko pa gre tudi za različne namene, ki jih Pavel in Luka zasledujeta (Pitta 2009, 126-128 in tam navedena literatura).

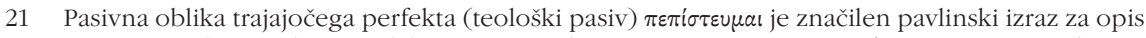
sprejetja poslanstva, ki ga podeljuje Bog sam (Rim 3,2; 1 Kor 9,17; 1 Tes 2,4; 1 Tim 1,11; Tit 1,3). 
Naslednji sad zbora v Jeruzalemu je vzpostavitev primerjave med Petrom in Pavlom ter potrditev temeljne enakovrednosti njunega poslanstva. Izstopa dvojna primerjava, ki ju Pavel s hiastično figuro poveže in tako še poudari: Kakor je bil Pavlu zaupan evangelij za neobrezane, tako je bil Petru zaupan evangelij za obrezane (v. 7b); kakor deluje Kristus v Petru zaradi obrezanih, tako deluje v Pavlu zaradi neobrezanih (v. 8). Pavel priznava Petru prvenstvo med apostoli, ${ }^{22}$ zato mu primerjanje $z$ njim veliko pomeni, kar je pokazal že ob prvem obisku Jeruzalema $(1,18)$. Kar na prvi pogled zmoti, je omemba dveh evangelijev: Evangelij za obrezane ( $\varepsilon \dot{a} \alpha \gamma \gamma^{\prime} \lambda ı \nu$

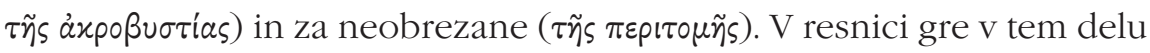
za precej neobičajno pavlinsko terminologijo in sintakso. ${ }^{23}$ Ker postavi Pavel kot izhodiščni problem pisma prav očitek, da se Galačani nagibajo k nekemu drugemu evangeliju, ki pa to ni, ker obstaja en samo »Kristusov evangelij« (1,6-7), lahko o dveh evangelijih govorimo samo kot o retorični figuri, ki v kontekstu misijonske strategije opozarja na različne pristope glede na naslovljence oznanila. (Vanhoye 2000, 60) Zbor je na koncu Pavla in Barnaba pooblastil, da oznanjata med pogani, Peter pa naj bi s svojimi sodelavci nadaljeval misijon med obrezanimi (1,9). Tudi ta delitev področij je sporna, saj vemo, da sta Peter in Pavel oznanjala tako Judom kot poganom (Apd 10-13) in da je Pavel tudi po tem dogovoru še naprej oznanjal tudi Judom ter si do konca prizadeval, da bi tudi oni sprejeli evangelij (Apg 16,$13 ; 17,2.10 .17 ; 18,4 ; 28,23-28 ; 1$ Kor 9,20). Izraza imata verjetno tukaj bolj retorično funkcijo. Z njima apostol poenostavi in konkretizira zapletena in večplastna vprašanja odnosa Cerkve do postave ter različnih pristopov pri oznanjevanju poganom in Judom. (Pitta 2009, 120) Konkretnih razlik sicer ne navaja, iz konteksta pa je jasno, da zanika obveznost obreze in drugih obrednih predpisov Mojzesove postave za sprejetje Božjega posinovljenja ter oznanja predvsem evangelij svobode v Kristusu $(2,4 ; 5,1.13)$. Njegov namen, da pokaže na enako vrednost, ki jo ima tako oznanjevanje poganom kot Judom, čeprav obstajajo tudi določene vsebinske razlike, pa je s to primerjavo dosežen.

22 O Petrovem prvenstvu je evangeljska tradicija enotna (Mt 10,2; 16,18-19; Mr 3,16; Lk 6,14; 22,31.32; Jn $1,42 ; 21,15-17)$ in jo potrjuje tudi Apd (1,15; 2,14.37-38; 3,4.12; 4,8 in dr.).

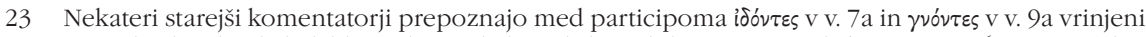
nepavlinski tekst, ki bi lahko tudi manjkal, ne da bi razbil prvotni stavek (Betz 1979, 96; Logennecker 1990, 55; Mußner 1981, 118). Domneve, da Pavel tukaj citira uradno grško besedilo zbora ali da se tekst nanaša na neko zgodnejše srečanje ali da gre za kasnejši dodatek, ki želi okrepiti Petrovo vlogo v Cerkvi, so se izkazale za premalo utemeljene. 
Tretji sad razprave na jeruzalemskem zboru je »spoznanje milosti« (2,9a:

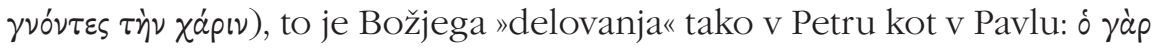

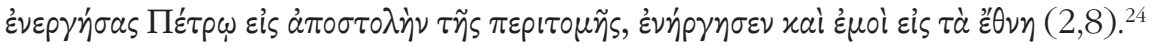
Pavel uporabi svojo tipično terminologijo, da pokaže na ustvarjalno moč Božjega delovanja tako v sebi (źmoi) in v Petru kot v njegovem poslanstvu

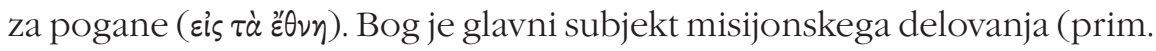
3,5). Pavel že v samem uvodu pisma razkrije, da je oznanjevanje evangelija Jezusa Kristusa in njegovega odrešenja delo »Boga Očeta, ki ga je obudil od mrtvih« (1,1-2), in ne človeško delo. To delovanje Boga v njem za poslanstvo oznanjevanja evangelija med pogani je »milost« $(\chi a ́ p ı s),{ }^{25} \mathrm{ki}$ jo je jeruzalemska Cerkev v njegovem delovanju prepoznala. Zaradi vsega tega so trije "stebri« ( $\sigma \tau \tilde{\imath} \lambda o \imath)$ jeruzalemske Cerkve - Jakob, Kefa in Janez -

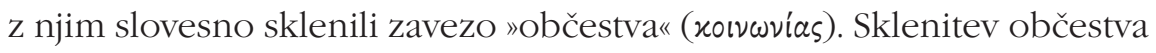
med Pavlom in jeruzalemsko Cerkvijo, do katerega sicer ni prišlo zlahka, kar je razvidno tudi iz delno nekoherentnega jezika v odlomku 2,1-10, še posebej v v. 4-6, predstavlja vrhunec Pavlove predstavitve jeruzalemskega zbora (Das 2014, 190) ter njegov najpomembnejši sad, ki je odločilno zaznamoval Pavlovo nadaljnje misijonsko poslanstvo ter njegov koncept cerkvene edinosti. (Hainz 2006, 127)

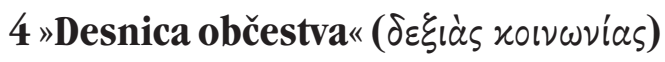

Izjava o sklenitvi občestva v 2,9 je zelo kompleksna in ključnega pomena za Pavlovo interpretacijo Cerkve, zato zasluži posebno pozornost. Okoliščine na jeruzalemskem zboru so morale biti precej napete in očitno ni bilo povsem jasno, ali bo Pavlu tam sploh uspelo doseči priznanje svojega apostolstva. ${ }^{26}$ Lahko bi prišlo celo do ekskomunikacije Pavla, ki je v Jeruzalemu pri marsikom (še vedno) veljal za odpadnika od postave (Apd 21,21-25). (Heinz 2006, 131) Zavrnitev Pavla bi pomenila tudi zavrnitev njegovega misijonarskega koncepta evangelija, ki človekovo opravičenje gradi izključno na Božjem delovanju po Kristusovi odrešenjski

24 Za teološki pomen gl. દ̇vepyéw glej 1 Tes 2,13; 1 Kor 12,6; Flp 2,13; Kol 1,29; Ef 1,11.20; 3,20.

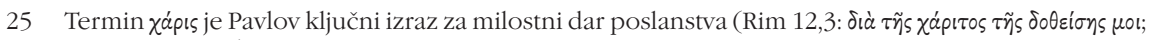
$\operatorname{Rim} 1,5 ; 15,15.16 ; 1$ Kor 3,10; Ef 3,2.7-8).

26 Smiles (1998, 38-49) dokazuje, da je šele Pavlova zaveza, da bo v svojih skupnostih organiziral pomoč za uboge v Jeruzalemu, zlomila upor njegovih največjih nasprotnikov. 


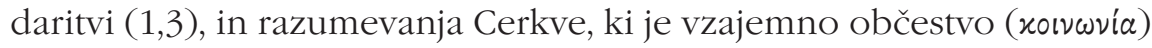
vernikov med seboj ter med verniki in Kristusom (1 Kor 1,9). Opravičenje in občestvo sta sad Božjega delovanja - milosti vere, ne sad izpolnjevanja del Postave $(2,16)$. Resnost situacije v Jeruzalemu, ko je dejansko grozil cerkveni razkol, razloži tudi ostrino Pavlovega apologetskega govora v prvem delu pisma, še posebej v Gal 1-2, kjer mora Pavel tudi v lastni skupnosti braniti resnico evangelija, ki so jo prej že prepoznali in potrdili »stebri« Cerkve.

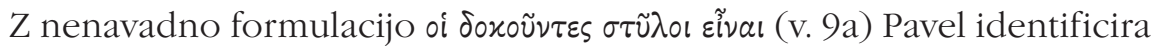
tri osebe med uglednimi v skupnosti, ki jim je predstavil svoj evangelij

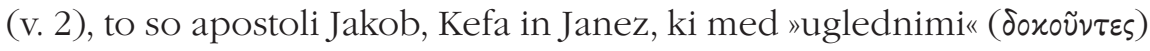
uživajo še poseben status, saj veljajo tudi za »stebre« - za vodilne apostole. (Mußner 1981, 120) Metaforična beseda $\sigma \tau \tilde{\lambda}$ or je bila znana tako v grškem kot $\mathrm{v}$ judovskem svetu, še posebej v judovski apokaliptiki, ${ }^{27}$ kot podoba trdnosti, večnosti, dostojanstva in reprezentančnosti. Z njo vzpostavi Pavel povezavo s podobo Cerkve kot zgradbe in apostolov kot njenih gradbenikov in oskrbnikov (1 Kor 3,9-17; 10,1-4; 14,3-5; Ef 2,19-22; 4,11-16; 1 Tim $3,15)$. Z uporabo te metafore za poimenovanje treh ključnih voditeljev Cerkve dobi Pavlov dogovor z jeruzalemsko skupnostjo širšo ekleziološko dimenzijo in veljavo. Vsi trije apostoli so igrali pomembno vlogo v zgodnji evangeljski tradiciji, še posebej Peter in Jakob. ${ }^{28}$ Gre za iste tri apostole, ki so bili prisotni pri Jezusovi spremenitvi na gori (Mr 9,2 vzp.), pri obuditvi Jairove hčere (Lk 8,51) ter prvi na seznamu učencev, zbranih ob Mariji v dvorani zadnje večerje po Jezusovem vnebohodu (Apd 1,13). Peter in Janez sta prva, ki po binkoštih oznanjata in ozdravljata v templju (Apd 3,1sl.). Postavitev Jakoba pred Petra ter uporaba aramejske oblike imena Kefa takoj po tistem, ko je bil prej dvakrat imenovan Peter (v. 7-8), daje sicer prostor za različne interpretacije, a kaže bolj na specifičen ekleziološki poudarek, ki ga želi Pavel doseči. Petrova dominantna vloga

27 Longennecker (1990, 56-57) navaja Talmud in rabinske izreke, ki imenujejo tri patriarhe, Abrahama, Izaka in Jakoba, kot stebre, na katere je postavljen Izrael in ves svet. To podobo so po njegovem mnenju gotovo poznali tudi aramejsko govoreči jeruzalemski kristjani in so jo lahko povezali z Jakobom, Kefom in Janezom kot s »stebri« Cerkve Nove zveze. O tem govori tudi Pitta (2009, 121-122). Takšno razumevanje patriarhov končno potrjuje tudi 1 QapGen, $v$ aramejskem jeziku zapisan esenski apokrif Geneze, ki (zato) popravlja podobo Abrahama in ga hkrati že predstavlja kot znanilca Nove zaveze. Radiokarbonska analiza je pokazala na čas nastanka 1QapGen med letoma 73 pr. Kr. in 14 po Kr. (Skralovnik 2018, 707-720). 
med apostoli v Cerkvi prvega stoletja je bila s tem še dodatno potrjena. (Vanhoye 2000, 61-62) Pavel mu priznava avtoriteto predstavnika celotne Cerkve in se obrača nanj kot na prvo avtoriteto (Gal 1,18-19; 2,7-8). Glede odnosa kristjanov do judovske tradicije pa se obrača na Jakoba, ki je veljal za voditelja jeruzalemske Cerkve $(2,12)$, kjer so prevladovali kristjani, zvesti Mojzesovi postavi. Jakob je tudi kot Jezusov sorodnik (1,19; Mr 6,3) užival v Jeruzalemu in v zboru apostolov posebno avtoriteto (Apd 12,17; 15,13; 1 Kor 15,7). Njegova javna potrditev apostolskega občestva s Pavlom je bila zato ključna za ohranitev edinosti prve Cerkve. (Mußner 1981, 123)

Sklepni prizor predstavlja slovesna potrditev Pavlovega poslanstva in občestva z njim s strani »stebrov« jeruzalemske Cerkve, kar so izrazili s »stiskom

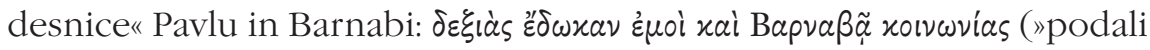
meni in Barnabu desnico občestva«) (2,9b). Gesta je tako v grško-rimski kot $\mathrm{v}$ judovski tradiciji razširjeno znamenje potrditve zaveze med dvema stranema ${ }^{29}$ in sama po sebi ne izraža superiornosti ene strani nad drugo. ${ }^{30}$ Pri interpretaciji tega slovesnega sklepnega dejanja je bila v preteklosti glavna pozornost namenjena samemu dejanju podaje desnice $\mathrm{v}$ potrditev dogovora, zanemarjen pa je bil večplastni pomen termina xoเvwvía. ${ }^{31}$ Beseda roเvwvía (skupnost, občestvo, deležnost, tovarišija, bratovščina, družba) tukaj ni uporabljena samo kot del metafore za sklenitev dogovora (Betz 1979, 100; McDermot 1975, 224), ${ }^{32}$ ampak ima tudi velik samostojni pomen, ki ga ima termin v teološkem kontekstu Pavlovih pisem.

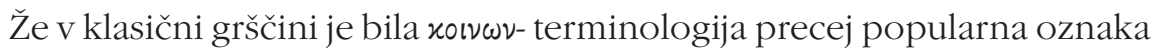
za povezovanje in združenja ljudi, mest in ljudstev, označevala je skupnost dobrin, bila pa je tudi del sakralne govorice kot občestvo med človekom

$292 \mathrm{Kr}$ 10,15; $1 \mathrm{Krn}$ 29,24; 1 Mkb 6,58; 11,50.62.66; 13,50; 2 Mkb 11,26; 12,11; Žal 5,6 (Betz 1979, 100; Das 2014, 190; Pitta 2009, 122).

30 V nekaterih primerih je lahko stisk roke tudi izraz podrejenosti (1 Krn 29,24; 2 Krn 30,8; Ezk 17,8),

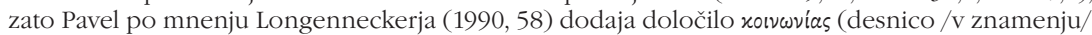
"tovarištva«).

31 Pregled študij o ekleziološkem pomenu termina xoเv山vía povzame Hainz (2006, 128-132), Kertelge $(1988,55-57)$.

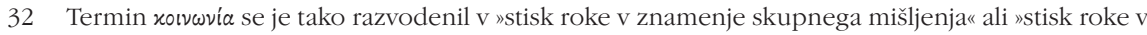
znamenje tovarištva" (Mußner 1981, 121). Tudi slovenski prevodi postavljajo različne poudarke: SSP: "so podali meni in Barnabu desnico v znamenje občestva«; JUB: "podali meni in Bárnabu desnico v znamenje vzajemnosti«; EKU: »podali meni in Barnabu desnico vzajemnosti«; CHR: »desnice meni in Barnabu v potrjenje tovarištva«; DAL: »inu fo meni inu Barnabu defne roké podali, inu fo fe s'nama s'glihali«. 
in božanstvom, v katero se je vstopalo večinoma z obrednim obedom. ${ }^{33}$ V judovsko-helenističnem kontekstu se je pomen te terminologije precej zožil,${ }^{34} \mathrm{~V}$ Novi zavezi, še posebej v Pavlovih pismih, pa pridobi termin

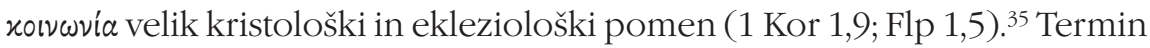
ima sicer različne vsebinske aplikacije, $v$ vseh primerih pa izraža tako vidike vzajemne notranje povezanosti med udeleženci kot deležnost občestva na nečem, kar povezuje in gradi. (Heinz 1981, 751) Natančna določitev pomena posameznega termina pa je mogoča samo na podlagi vsakokratnega konteksta, ki ga sestavljata tako neposredno sobesedilo kot širši kontekst, ki ga opredeli struktura pisma. Oba konteksta igrata tudi pri interpretaciji

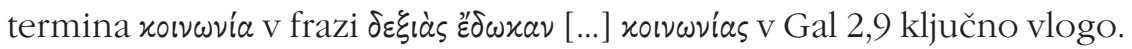

Izjava v v. 9 o podaji »desnice občestva« predstavlja vrh v odlomku 2,1-10, ki je sestavni del prve apologetsko-doktrinalne enote pisma $(1,1-2,21) .{ }^{36}$

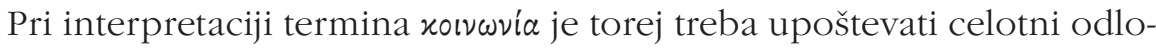
mek (2,1-10) ter tudi celotno prvo enoto pisma (Gal 1-2). Enota in odlomek vsebujeta tako vidike vsebinske konotacije »resnice evangelija (npr. 1,4.6.11-12.15-16; 2,5.8.16), ki ga Pavel in drugi apostoli oznanjajo, kot različne okoliščine oznanjevanja (npr. 1,7-10.17-24; 2,1-4.11-14). Ta širši kontekst

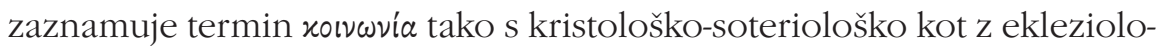
ško konotacijo. Pavel in apostoli so namreč potrdili, da njihovo občestvo temelji na razodetem evangeliju o Jezusu Kristusu, »ki je daroval sam sebe za naše grehe« in tako uresničil voljo Boga Očeta $(1,4)$. Pavel Galačanom

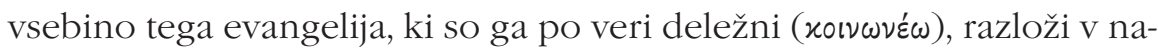
daljevanju pripovedi, kjer poroča o konfliktu v Antiohiji, ki se je izkazal za prvi preizkus sklenjenega občestva (2,11-14). Novost evangelija je, da gre

33 Pri Homerju izraz xoเvwvós označuje udeležence pri obrednih obedih, ki se z uživanjem hrane in s spolnim aktom združujejo z božanstvi, sprejemajo njihove moči in ustvarjajo občestvo z njimi. Helenistična mistika pozna psihična občestva med božanstvom in človekom. Tudi Filon Aleksandrijski pozna termin xoเvavía kot religiozno udeležbo in občestvo, ki preko delovanja logosa nastaja med človekom in božanstvom. (Hauck 1967, 800-803)

34 Septuaginta prevaja s termini xoเvav- hebr. רבח (tovariš, tovarištvo, družabnik, družica, društvo) (Iz 1,23; Mal 2,14), vendar vedno le v profanem, nikoli v transcendentnem ali religioznem pomenu, ter pri tem izpostavlja razliko med človekom in Bogom. (Hauck 1967, 801) Ko preroki svarijo pred razvratnimi poganskimi kulti, ki želijo vzpostavljati neko povezavo med ljudstvom in maliki, LXX ne

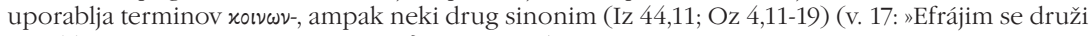

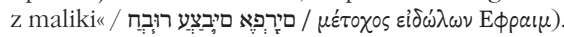

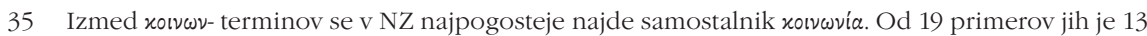
v Pavlovih pismih, skoraj izključno v pomembnih kristoloških (1 Kor 1,9; 10,16-17; 2 Kor 13,13; Flp 3,10) ali eklezioloških kontekstih (Rim 15,27; 2 Kor 9,13; Flp 1,5; 2,1; Flm 1,6).

36 Po Betzu (1979, 14-23) se v 3,1 začne nova enota argumentiranja Pavlove ključne teze v 2,16.

Edinost in dialog 74 (2019) 1: 175-193 
za zastonjski dar Boga, ki se je uresničil po Kristusovi daritvi. Verniki imajo zato dostop do tega daru "po veri v Kristusa in ne po delih postave $(2,16 \mathrm{~b}$ :

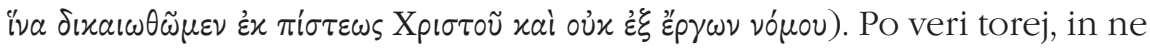
po delih postave, postajajo verniki deležni tudi tega novega občestva, ki je nastalo po oznanjevanju evangelija, ki je bil Pavlu zaupan "za neobrezane»

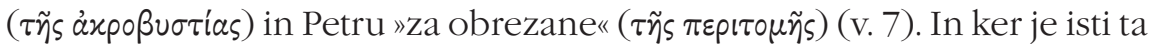

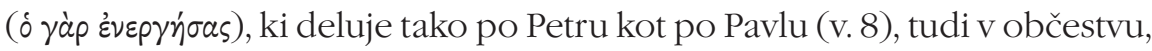
ki je sad evangelija, ne more biti razlike med obrezanimi in neobrezanimi.

Določene težave z interpretacijo "zaveze občestva« je v zgodovini eksegeze povzročala sklepna izjava, ki predstavlja končni namen sklenitve občestva:

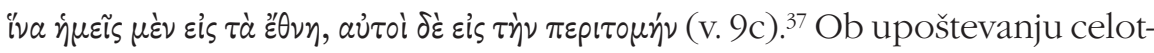
nega konteksta je mogoče sklepno iva-stavčno konstrukcijo interpretirati samo finalno, in ne pogojno. ${ }^{38}$ Zaveza občestva ni bila sklenjena pod pogojem, da Pavel omeji svoje oznanjevanje na pogane oziroma na nejudovska ljudstva, oznanjevanje evangelija Judom pa prepusti Jakobovemu krogu. V tem primeru bi xoเvwvía, ki so jo slovesno potrdili, pomenila zgolj sobivanje in kompromis za vzdrževanje premirja in delitev teritorija. ${ }^{39}$ Takšno premirje bi prej ali slej pripeljalo do konflikta, ki ga Pavel ilustrira že takoj v nadaljevanju (2,11-14), ko spregovori o sporu s Kefom, ki je zatajil svoje novo evangeljsko mišljenje iz strahu pred Jakobovimi sodelavci. Pavel s to kontrastno pripovedjo takoj za poročilom o sklenitvi zaveze med njim in jeruzalemsko skupnostjo ne zmanjšuje Petrove vloge v prvi Cerkvi, prej nasprotno, saj ga ne samo imenuje z izvornim aramejskim imenom Kefa, kar utrjuje njegovo avtoriteto, ampak ga postavi tudi v določeno distanco z Jakobovim krogom. Hkrati pa pripoved vsekakor pokaže tudi na težavnost procesa osvobajanja krščanstva od ozkih okvirov judovske tradicije in sprejemanja novega evangeljskega mišljenja. Konflikt še zaostri razlaga, da se je Kefa začel ogibati skupnim obedom s pogani »iz strahu pred ob-

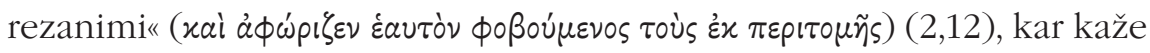

37 Pregled različnih interpretacij predstavita Hainz (2006, 133-134) in Mußner (1981, 122-123).

38 Blass-Debrunner, \391,3, razume veznik iva v Gal 2,9 pogojno: "pod pogojem, da greva midva med pogane, oni pa med obrezane«), kar pa nasprotuje smislu neposrednega in širšega konteksta, ki izraža Pavlov primarni namen pisma.

39 Preveč poenostavljena je predstava, da sta v prvem stoletju obstajali že dve skupini oznanjevalcev evangelija: ena za misijon med Judi, ki naj bi delovala pod Petrovim vodstvom, ki pa naj bi bil pod močnim Jakobovim vplivom, druga pa za misijon med pogani pod Pavlovim in Barnabovim vodstvom, kar pa glede na Gal 2,7-9.11-14 nima prave osnove. (Mußner 1981, 122) 
na trdovratno zakoreninjenost v starem mišljenju. Ostrina konflikta spodbudi Pavla k še bolj jasnemu in brezkompromisnemu nastopu za resnico evangelija in k iskanju razlogov za edinost krščanskega občestva. Konflikt in kritika v skupnosti pripomoreta k prečiščevanju temeljnih principov, na katere sta postavljena, $s$ tem pa se tudi celotna skupnost prečiščuje, povezuje in motivira za svoje temeljno poslanstvo ter tako vzpostavlja še trdnejše občestvo. (Söding 2016, 89)

\section{Sklep: občestvo edinosti in vključevanja}

Termin xoเvwvía ima v Pavlovih pismih v prvi vrsti izrazit kristološki in ekleziološki pomen. Tako označuje najprej novo skupnost vernikov, ki jih Bog Oče po svojem Sinu kliče (1 Kor 1,9), da bi živeli v tesno prepleteni življenjski povezanosti z njim in med seboj. Izvor tega občestva je krst (Gal 3,27), središče pa evharistični obed, ko verniki po uživanju blagoslovljenega keliha in kruha postajajo deležni Kristusovega telesa oziroma postajajo

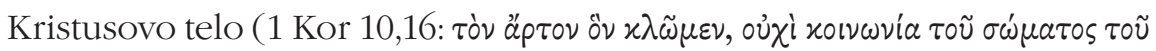

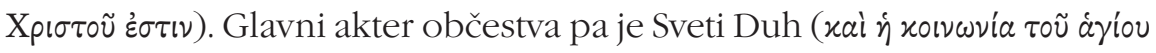
$\pi \nu \varepsilon \dot{\mu} \mu \tau \tau o \varsigma)$, ki oblikuje občestvo po podobi Svete Trojice, kar Pavel najbolj jasno izrazi v sklepu Drugega pisma Korinčanom $(13,13)$. Apostol povsod poziva vernike, da dejavno živijo občestveno obliko novega življenja, ki več ne postavlja v središče ne lastnih privilegijev, kot so etnična pripadnost, stan in spol (prim. Gal 3,28), ne lastnih pridobitev, kot so opravljanje del postave in religioznih predpisov (prim. Gal 2,16), temveč vero v Jezusa Kristusa, ki je zanje daroval sam sebe (Gal 1,4), da bi tudi oni po krstu v njegovo skrivnost postali Božji sinovi (Gal 3,26). To je tudi temeljna vsebina Pavlovega evangelija, ki mu je bil razodet in iz katerega so se rodile krščanska občestva. Ena osnovnih značilnosti teh občestev vernikov, ki se zavedajo daru evangelija, je zato "predano pričevanje» (2 Kor 9,13:

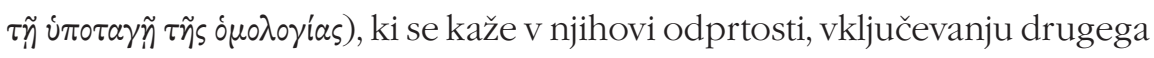
in dobrodelnost. Pavel takšno občestvo označi kot velikodušno, svobodno,

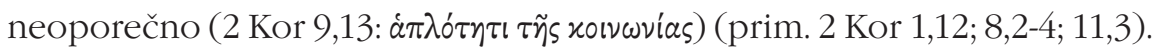

Vključevanje drugega in dobrodelnost sta tudi značilnosti »apostolskega občestva«, ki so ga slovesno potrdili predstavniki Cerkve ob sklepu apostolskega zbora v Jeruzalemu ( Gal 2,9). Iz zaključnega poziva apostolov, naj se Pavel in Barnaba spominjata »revežev« $(2,10 \mathrm{a}$ : $\mu$ óvov $\tau \tilde{\omega} \nu \pi \tau \omega \chi \tilde{\omega} \nu$ iva 
$\mu \nu \eta \mu о \nu \varepsilon v ́(\mu \varepsilon v)$, postane še bolj očitno, da je skrb za reveže oziroma dejavna ljubezen do bližnjih eden najbolj prepričljivih izrazov cerkvenega občestva (xovvwía), kakor ga razume Pavel. (Mußner 1981, 124; Vanhoye 2000, 62) 40 $^{40}$ $S$ poudarjenim predlogom róvov (samo, zgolj) Pavel samo še bolj izpostavi, da mu apostolski prvaki glede "resnice evangelija - glede vsebine njegovega oznanila - niso naložili ničesar dodatnega (v. 6), skrb za reveže pa spada k načinu oznanjevanja, ki ga določa že samo bistvo evangelija. Kdo konkretno so ti reveži $(\pi \tau \omega \chi 0 i),{ }^{41}$ za katere naj bi skrbela Pavel in Barnaba, iz samega teksta ni razvidno. V velikih pismih Pavel pogosto omenja nabirko za Cerkev v Jeruzalemu (prim. Rim 15,25-32; 1 Kor 16,1-4; 2 Kor 8,1-9,16), a večinoma dodaja ime »sveti« (oi ä $\gamma(\circ)$ ), kar je zanj drugo ime za vernike (prim. Rim 1,7; 1 Kor 1,2). V Rim 15,26 imenuje nabirko

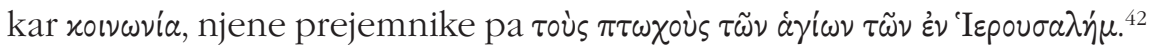
Ta opredelitev revežev se izkaže za najustreznejšo tudi glede prejemnikov Pavlove pomoči v Gal 2,10. (Longennecker 1990, 60)

Poleg kristološke in ekleziološke dimenzije pridobi torej Pavlov kon-

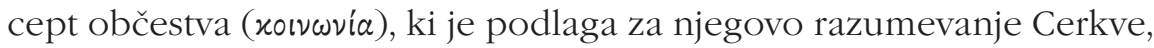
v Pismu Galačanom močno univerzalno-ekumensko in misijonsko-etično dimenzijo. Z apostolskim priznanjem in potrditvijo Pavlove misijonske strategije ni bila priznana samo popolna enakopravnost med Pavlovim in Petrovim oznanjevanjem, temveč tudi med naslovljenci tega oznanila - med Cerkvami, ki so izšle iz narodov in kultur, ter Cerkvijo, ki je izšla iz zaveze in bibličnega izročila. (Söding 2003, 118-120) Ker je občestvo utemeljeno na skupni veri v Jezusa Kristusa, je ne more več usodno ogroziti ne različnost med Judi in Grki ne med sužnji in svobodnimi ne med moškimi in ženskami (Gal 3,28; 1 Kor 12,12-13), ampak je s tem usposobljeno za univerzalno poslanstvo. Temelj te edinosti in univerzalnosti je »enost

40 Pavlovo razumevanje revščine je močno prežeto s starozaveznim, »rabinskim« razumevanjem odnosa do revščine (Skralovnik in Matjaž 2017, 19-46).

41 V grškem svetu sta revščino označevala pridevnika $\pi \tau \omega \chi o_{\text {ś }}$ in $\pi \varepsilon ́ v \eta \varsigma$. Prvi v grškem svetu največkrat opisuje revnega posameznika, ki je živel na robu ali celo pod minimalno mejo preživetja, medtem ko drugi označuje situacijo, v kateri je posameznik z delom lahko zaslužil dovolj za preživetje sebe in družine. Z vidika terminologije, ki jo novozavezni pisci uporabljajo za opis revščine, ločnica med

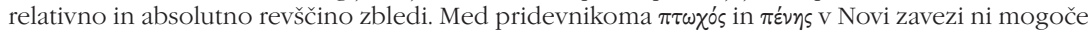
več razbrati različnih nivojev revščine. To dejstvo ni posebnost navdihnjenih pisateljev 1. stoletja po Kr., ampak lahko to opazimo že vsaj tri stoletja prej v prevajalskih rešitvah Septuaginte. (Skralovnik 2015, 92-93)

42 Za več glede razlogov za Pavlove nabirke glej Mußner (1981, 124-125) in Pitta (2009, 124-125) ter tam navedeno literaturo. 


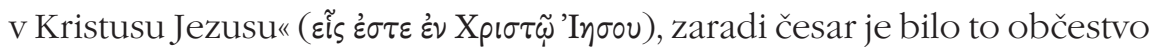
sposobno prestati tudi številne konflikte - ne samo prvega, ki se je takoj nato pojavil $\mathrm{v}$ Antiohiji (2,11sl.), ampak tudi druge napetosti in stiske, o katerih Pavel pogosto poroča (1 Tes 2,14-16; 1 Kor 1,10-13; 2 Kor 1,8-11; 3,14-16; Rim 2,1-11) - in ohraniti edinost. Koinonia, ki je bila priznana in potrjena v Jeruzalemu, ne pomeni uniformiranosti, ampak je sposobna vključevati tudi različnost in z njo živeti. Ta lahko postane izziv za rast ljubezni in vere, o čemer pričuje Pavel ob konfliktu glede uživanja malikom žrtvovanih jedi v Korintu (1 Kor 8,7-13).

Koinonia, ki je bila vzpostavljena v Jeruzalemu, pomeni končno dejavno in dinamično občestvo, kar se kaže v načinu življenja občestva (etos) in v njenem misijonskem poslanstvu. V sklepu pisma Pavel tako povzame, da je

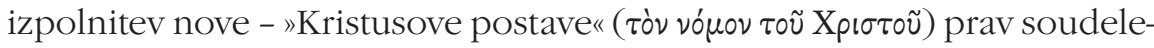
ževanje ( v delitvi dobrin drug z drugim (6,2-6). S tem tudi sporoča, da se misijonsko poslanstvo občestva ne uresničuje samo z oznanjevanjem teološke resnice evangelija, temveč tudi z ustvarjanjem novega načina življenja, ki izhaja iz evangelija in se kaže v edinosti in ljubezni. Ta proces je zahteven, ker pomeni sleči starega človeka in »obleči Kristusa" $(3,27)$. Pavel ga opisuje celo s križanjem $(2,19)$, to je z umiranjem starega človeka, ki je živel po Postavi - to je na človeški, na individualni način, ter rojevanje novega, ki živi »iz vere v Božjega Sina« $(2,20)$, to je na občestveni način. Ne novega življenja ne oznanjevanja evangelija ni mogoče živeti kot posameznik, temveč le kot občestvo. Zato je po Pavlu tudi danes glavno poslanstvo Cerkve, da s povezovanjem in vključevanjem ustvarja prostor, kjer se lahko razodeva novo - občestveno življenje (2 Kor 13,13).

\section{Reference}

Betz, Hans Dieter. 1979. Galatians. A commentary on Paul's Letter to the Churches in Galatia. Philadelphia: Fortress Press.

Gieniusz, Andrzej. 2018. 'Inesperto nell'arte di parlare'? (2 Cor 11,6). Retorica al servizio del Vangelo. Città del Vaticano: Urbaniana University Press.

Hainz,Josef. 2006. Gemeinschaft (KOINWNIA) zwischen Paulus und
Jerusalem (Gal 2,9f). Zum paulinischen Verständnis von der Einheit der Kirche. Neues Testament und Kirche. Gesammelte Aufsätze, 125-136. Regensburg: Verlag Friedrich Pustet. - - -. 1981. xolvwvía. EWNT II: 749-755.

Hansen, G. Walter. 1989. Abraham in Galatians: epistolary and rhetorical 
contexts. Sheffield: Academic Press.

Hauck, Friederich. 1950. xoเvós. ThWNT III: 789-810.

Kertelge, Karl. 1988. Koinonia und Einheit der Kirche nach dem Neuen Testament. V: Josef Schreiner et al., ur. Communio Sanctorum. Einheit der Christen-Einheit der Kirche. Festschrift für Bischof Paul-Werner Scheele, 53-67. Würzburg: Echter.

Longenecker, Richard N. 1990. Galatians. Waco: Word Books.

Lührmann, Dieter. 1978. Der Brief an die Galater. Zürich: Theologischer Verlag.

Matera, Frank J. 1992. Galatians. Collegeville: Liturgical Press.

Matjaž, Maksimilijan. 2012. Gospel in confrontation with culture: Paul's speech in Athens. Bogoslovni vestnik 72 : 567-576.

Mußner, Franz. 1981. Der Galaterbrief. Auslegung. Freiburg: Herder.

Od konflikta do skupnosti. Skupno luteransko-katoliško obeleževanje reformacije leta 2017. Poročilo luteransko-rimokatoliške komisije za edinost. 2016. Ljubljana: Družina.

Pitta, Antonio. 2008. Paolo, la Scrittura e la Legge. Antiche e nuove perspettive. Bologna: Edizioni Dehoniane.

- - -. 2009. Lettera ai Galati. Introduzione, versione e commento. Bologna: Edizioni Dehoniane.

Schnelle, Udo. 2003. Paulus. Leben und Denken. Berlin, New York: Gruyter.

Schwartz, G. 1992. Zum Wechsel von »Kephas« $\mathrm{zu}$ »Petros« in Gal 1 und 2. Biblische Notizen 62: 46-50.
Skralovnik, Samo. 2018. Podoba Abrahama v kumranski apokrifni Genezi (1QapGen). Bogoslovni vestnik 78: 707-720.

- - -. 2015. Relativna in absolutna revščina v hebrejščini, v klasični in v novozavezni grščini. Bogoslovni vestnik 75: 79-98.

Skralovnik, Samo, in Maksimilijan Matjaž. Izziv revščine $v$ nekaterih mezopotamskih zakonikih in Svetem pismu. Studia Historica Slovenica 17: 19-46.

Smiles, Vincent M. 1998. The Gospel and the law in Galatia: Paul's response to Jewish Christian separatism and the threat of Galatian apostasy. Collegeville: The Liturgical Press.

Smit, Joop F. M. 1989. The Letter of Paul to the Galatians: a deliberative speech. New Testament studies 35: 1-26. https://doi. org/10.1017/s0028688500024474

Söding, Thomas. 2003. Ekklesia und Koinonia. Grundbegriffe paulinischer Ekklesiologie. Catholica 57: 107-123.

- - -. 1991. Die Gegner des Apostels Paulus in Galatien. Beobachtungen zu ihrer Evangeliumsverkündigung und ihrem Konflikt mit Paulus. Münchener theologische Zeitschrift 42: 305-321.

- - -. 2016 Streiten verbindet. Der Galaterbrief als Wegweiser der Ökumene. V: Ulrich Luz, Thomas Söding, in Samuel Vollenweider, ur. Exegese - ökumenisch engagiert. Der "Evangelisch-Katholische Kommentar in der Diskussion über 500 Jahre Reformation. Ein Rückblick und ein Ausblick, 89-97. Ostfildern; Göttingen: Patmos; Vandenhoeck \& Ruprecht. https://doi. org/10.13109/9783788731823.89

Stanley, Christopher D. 1998. Biblical quotations as rhetorical devices in Paul's letter to the Galatians. Seminar papers $S B L$ 37: 700-730.

Vanhoye, Albert. 2000. Lettera ai Galati Nuova versione, introduzione e commento. Milano: Paoline. 